\title{
Description of Physical Activities in the Elderly with Hypertension in Posbindu Sumber Sehat, Demak Regency
}

\author{
Edy Soesanto, Khoiriyah Khoiriyah*, Ike Fitri Handayani \\ Departement of Nursing, University of Muhammadiyah Semarang, Semarang, Indonesia
}

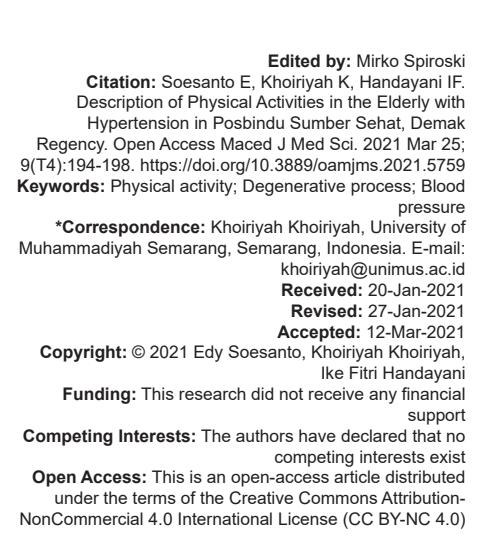

Introduction

Increased welfare, health, and the number of elderly populations in a country are often associated with an increase in life expectancy [1]. Ministry of Health Republic Indonesia estimated life expectancy is 71.9 in $2020-2025$. There is an 18.27 million elderly population in Indonesia based on the Statistics of the Elderly Population in Indonesia in 2011 or around $7.58 \%$ of the total population of Indonesia. The Central Statistics Bureau in 2015 also stated that Indonesia was ranked number 4 , with the largest number of elderly populations [2].

This can reflect the progress of a country because a developed country is an increasingly healthy nation with a large elderly population and a nation that has a long life expectancy [1]. The process of aging (degenerative) is a natural process that cannot be controlled by someone and is a physiological process of the body in every human being [3].

Based on the WHO data, it is categorized as elderly when someone is at the age of 60 years and over. Where at this age, the elderly will gradually experience a decline in function both in terms of biological, psychological, social, spiritual as well as all functions of their organs and systems [3]. Associated with physiological changes in the cardiovascular system in humans, there are some changes that occur during humans in the adult age period. The heart muscle will lose its efficiency and contractile strength when humans are in adulthood so that it will reduce cardiac output in conditions of physiological stress. Pacemaker cells will become irregular and decrease in number, and the sheath that surrounds the sinus node thickens. Contractions and relaxation time in the left ventricle require a lot of time. The diastolic filling and systolic emptying cycle require more time to complete [4].

The degenerative process of the elderly can cause a variety of very complex disorders that can be life-threatening. One of the disorders that are often experienced by the elderly is cardiovascular disorders, which are disruptions of the blood vessel system. The disruption of the blood vessel system is a result of decreased organ function and blood pressure lability that occurs naturally in the body of the elderly [5]. This cardiovascular disorder results in decreased relaxation of vascular smooth muscle, which can result in atherosclerotic conditions and conditions of loss of connective tissue elasticity resulting in decreased ability to stretch and decreased ability of blood vessels to stand up [6]. Various decreases that occur gradually will be marked by a decrease in the level of activity [7]. 
From the survey results of the Indonesian Central Statistics Agency for Elderly in 2011, chronic diseases, one of which is hypertension, reached $28.53 \%$ for young elderly, $38.26 \%$ for middle-aged elderly, and $44.27 \%$ for elderly. Judging from pathophysiological activity, hypertension can be said as a "silent killer" disease [8]. High blood pressure occurs when systolic blood pressure increases, which ranges from more than $140 \mathrm{mmHg}$ (millimeters of hydrogen), and diastolic blood pressure more than $90 \mathrm{mmHg}$ (millimeters of hydrogen) [9]. The uncontrolled hypertension can make sufferers have a 7 times greater chance of stroke, 5 times greater chance of heart failure, and 3 times greater heart attack [8].

Therapy to cure hypertension is through pharmacological therapy and non-pharmacological therapy [10]. One of the activities or nonpharmacological therapy activities is by living a healthy lifestyle, sedentary people lifestyle, creating a relaxed atmosphere, and doing light physical activity [11]. Physical activity is all activities carried out in a planned, structured, and repetitive manner that requires some energy to do it, which aims to improve physical fitness. The elderly physical activity has an impact on changes in the strength of the smooth muscle in the heart so that the pulse in the heart can be strong and regular [12].

The United States Department of Health and Human Services mentions several levels of physical activity. The level of physical activity includes the level of inactive (inactive), low activity (low-level activity), medium activity (moderate level activity), and high activity (high-level activity) which is determined in minutes range based on the standard of physical activity carried out for 1 week. It also divides physical activity categories, which include activities with moderate intensity and activities with strong intensity (vigorous intensity) [13].

Physical activity is very influential on high and low blood pressure. This research shows that physical activity, such as walking, can reduce blood pressure, especially systolic blood pressure. Systolic blood pressure pre- and post-walking activity in the elderly shows different figures. Both showed a significant decrease. Systolic blood pressure pre-physical activity ranges from $140 \mathrm{mmHg}$ to $158 \mathrm{mmHg}$, whereas systolic blood pressure post walking activity shows the number 133-153 mmHg. The walking activity intervention was carried out for 8 weeks, with 40 interventions [11].

Based on Central Statistics Agency of Demak Regency in 2010, Demak Regency was the regency with the highest population in Central Java with a population of 1177 people/km, and the highest population in Demak was occupied by Mranggen District with 158,597 inhabitants. The majority of the elderly population in Demak Regency lives in rural areas. Kangkung Village, Mranggen Subdistrict, Demak Regency is one of the villages where the majority of the population is elderly [14].
Based on data from the Community Empowerment and Family Planning Board of Demak Regency, there are $13.4 \%$ of the total population of Kangkung Village, which is around 7478 residents, are the elderly population or equivalent to 726 elderly residents in the Kangkung Village. The results of the elderly visit data from the Mranggen Community Health Center in 2012 also explained that the disease most often suffered by the majority of the elderly in Kangkung Village was hypertension with $57 \%$ presentation.

Based on an interview conducted on 28 December 2018 at 19.30 with the local cadre leader, data were obtained that RW 05 Kangkung Village, Mranggen Subdistrict Demak Regency had a Posbindu that was formed in 2009 and was named Posbindu "Sumber Sehat" and according to the Cadre Chair most of the elderly in Kangkung Village is the elderly who mostly suffer from non-communicable diseases of hypertension. Based on the results of interviews, most of the elderly in the Kangkung Village perform physical activities according to the ability of the elderly. Physical activity in the elderly in Kangkung Village is a medium intensity activity category.

The head of the cadre said that the elderly in the village of Kangkung work as farmers and housewives. They work from morning till late afternoon, so to do some kind of routine and controlled activities is very difficult because the elderly do not have much time to do some selected routine and regular physical activities as an effort to prevent hypertension. The cadre leader also added the causative factor that made the elderly suffer from hypertension, which was due to the poor lifestyle of the elderly, which was proven by the elderly who rarely did sports or physical activities so that the disease did not cause contagious hypertension in the Kangkung Village. There were $59.6 \%$ of the elderly in Kangkung Village did not do regular sports activities [15].

\section{Methods}

This type of research was descriptive, with a cross-sectional design [16]. In this study, the population was elderly with hypertension in Posbindu Sehat source in Kangkung Village, Mranggen district, Demak Regency. The method used the Probability sampling method with the Proportional Stratified random sampling approach so that it became 63 respondents [17]. This study was conducted on elderly patients with hypertension in Posbindu Sumber Sehat in Kangkung Village, Mranggen District, Demak Regency. Data collection tools use observation sheets or research questionnaires from Global Physical Activity Questionnaire (GPAQ). 
The research process lasts from January to June 2019. The data were analyzed univariately.

\section{Results and Discussion}

The characteristics of respondents were mostly female that was 63 respondents (100\%). Most of the average age in the elderly age category (60-74 years) were 28 respondents (44.4\%). Most respondents had low education, namely, as many as 63 respondents $(100 \%)$, and some respondents did not work as many as 41 respondents (65.1\%).

Results characteristics of respondents were mostly female. Namely, 63 respondents (100\%), most of the average age in the elderly age category (6074 years) were 28 respondents (44.4\%), the education of most respondents had low education namely as many as 63 respondents (100\%), and some respondents did not work as many as 41 respondents (65.1\%).

Based on the results of the study, the description of physical activity in hypertensive elderly data obtained that most of the elderly included in the category of moderate physical activity as many as 38 people $(60.3 \%)$. As many as, 13 people $(20.6 \%)$ were included in the category of mild physical activity and 12 people (19.0\%) were included in the category of strenuous physical activity. Factors that influence hypertension, include age, education, work, and exercise or exercise habits. These factors are proven to be statistically related to blood pressure, which can be proven from the results of $p$-value where $(p<0.05)$ [18]. Moderate-intensity physical activity could reduce systolic pressure by 11 points and diastolic pressure by 8 points. This medium-intensity activity is an activity that makes a person able to hold his body weight like walking or activities that cannot directly hold his body weight like cycling [8].

There was a good relationship between physical activity and blood pressure in the elderly with hypertension with $p=0.012(\alpha=0.05)$. The study showed that respondents with a good physical activity category had mild hypertension. Active respondents walked (20 $\min$ in $1.6 \mathrm{~km})(45.2 \%)$ and swept dry leaves (45.0\%) so that the highest systolic blood pressure was 150 $\mathrm{mmHg}$ with a diastolic pressure of $90 \mathrm{mmHg}$ [19].

Physical activity is the movement of all body members that can be a cause of energy expenditure, which is very important for the maintenance of physical, mental health, and maintaining the quality of life to stay healthy throughout the day [20]. Physical activity can help improve one's health condition. In this study, physical activity was categorized into three categories, namely, mild physical activity, sedan physical activity, and strenuous physical activity. Categories of physical activity are grouped based on questions from the GPAQ. The GPAQ divides questions into six subcategories of questions.

Among the respondents', questions were questions regarding heavy work activities, light work activities, activities during transportation, and recreational activities. Strenuous sports, moderate recreational/sports activities, and sedentary activities. The heavy work activity studied was how long and how often a person does heavy activities such as reading heavy items, gardening, cycling, and lifting heavy items. In light work activities that are studied are physical activities, which include $40 \%$ of the actuary used is to sit and stand, and $60 \%$ for specific work activities in the field of work. Examples of activities that were examined in the sub-section of moderate work activities are washing vehicles, cycling going and going back to activities, moderate and fast walking, scrubbing the floor, washing vehicles, and planting plants. The transportation activity that was investigated included how long a person traveled to the place of activity or when shopping and worshiping outside the home, which was done at least 10 min routinely either using a vehicle such as a motorcycle, bicycle, or on foot.

Recreational activities or sports activities that are meticulous are how long and often a person performs recreational activities/sports, both heavy sports and sports/recreation classified as moderate such as brisk walking, swimming, and cycling, which can result in increased breathing and pulse at least 10 min routinely. The heavy leisure/sports sub-activities studied were the intensity and duration of the respondents regarding strenuous sports and leisure activities, which included running and soccer. Then, the third sub concerns sedentary activities.

This sedentary activity is an activity that does not require much movement, such as sitting when working, sitting in a vehicle, lying down, or watching television. Regular physical activity can increase heart efficiency. In general, someone who has acted in activities tends to have lower blood pressure and less frequent high blood pressure. The reason is that someone active will have stronger and more flexible muscle and joint function and can maintain fitness and cardio-respiratory endurance [4]. Changes in the body are obtained when a person regularly performs activities. Physical activity can eliminate cholesterol deposits and blood vessels, smooth muscle in the heart will tend to be stronger so that the pulse and frequency are strong and regular, in addition to the elasticity of blood vessels will increase due to relaxation and vasodilation so that fat deposits are reduced and can increase muscle contraction blood vessel wall.

The damage of the heart and blood vessels due to increased working system of heart muscle and blood vessels. Conversely, the heart pump power condition that is less than optimal will occur in someone who tends to be low in an activity where when a person's 
activity is low, blood flow in the body is not smooth. Physical activity is very important to do to form strong heart muscle when pumping blood. This can be seen from the facts in the field wherefrom the results of using a questionnaire based on the GPAQ obtained data that the elderly hypertension who are moderate physical activity as many as 38 people (60.3\%), as many as 13 people $(20.6 \%)$ included in the category of mild physical activity, and 12 people (19.0\%) of whom were included in the category of heavy physical activity (Table 1).

Based on the results of the study, there are a variety of MET values of elderly people with hypertension, which include activities with MET-minute/week values ranging from the lowest value of $0 \mathrm{MET}$-min/week and the highest value of $7480 \mathrm{MET}$-min/week. The study results obtained data of 38 respondents $(60.3 \%)$ have a MET value in an interval of $3000>M E T \geq 600$ so that it can be categorized as physical activity with a moderate category. A total of 13 respondents $(20.6 \%)$ had a MET value in the interval $600<\mathrm{MET}$, which included in the category of light activity. Based on the result of the study there are 12 respondents (19.0\%) elderly hypertension with heavy activity. The MET values of all hypertensive elderly people have an average of $1757.97 \mathrm{MET}$-min week at an interval of $3000>$ MET $\geq 600$ so that it can be mentioned from these results that most of the physical activity of the elderly with hypertension in Posbindu is a healthy source in the village of Kangkung sub-district Mranggen district Demak and is included in the category of moderate physical activity. The median average yield for total physical activity was 1320.00 with a standard deviation of 1576,960 .

The study results also explained that the longest time needed to perform physical activity is when the activity is working. MET-minute/week values for activities when recreation and transportation do not differ greatly. The results showed that the time spent on sedentary activities was longer so that it could be said that the elderly tended to be passive in their activities

Table 1: Frequency distribution of respondents based on the characteristics of hypertensive elderly respondents in the Kangkung Village, Mranggen District, Demak Regency

\begin{tabular}{lll}
\hline Characteristics & Frequency ( $\mathrm{n})$ & Percentage \\
\hline $\begin{array}{l}\text { Gender } \\
\quad \text { Girl }\end{array}$ & 63 & 100.0 \\
Age & & \\
$\quad$ Middle age (45-59 years) & 16 & 25.4 \\
$\quad$ Elderly (60-74 years) & 28 & 44.4 \\
$\quad$ Old (75-90 years) & 19 & 30.2 \\
Education & & \\
$\quad$ No school & 63 & 100.0 \\
Work & & \\
$\quad$ Does not work & 41 & 65.1 \\
$\quad$ Farmers & 22 & 34.9 \\
Hypertension & & \\
$\quad$ Mild Hypertension & 34 & 54.0 \\
$\quad$ Moderate hypertension & 16 & 25.4 \\
$\quad$ Severe hypertension & 13 & 20.6 \\
Physical activity & & \\
$\quad$ Light activities & 13 & 20.6 \\
$\quad$ Medium activity & 38 & 60.3 \\
$\quad$ Heavy activity & 12 & 19.0 \\
Types of activities & & \\
$\quad$ Work hard & 23 & 63.5 \\
$\quad$ Working medium & 46 & 73.0 \\
$\quad \begin{array}{l}\text { Transportation } \\
\text { Recreation }\end{array}$ & 32 & 50.8 \\
\hline
\end{tabular}

compared to the time for recreation and transportation. That is due to the elderly who are getting weaker and easily fatigued when doing a little activity even though the activity is relatively mild such as walking slowly, washing dishes, and cooking.

The average MET-minute/week value based on each activity category is 1302.22 MET-min/week for work activities, $168.58 \mathrm{MET}$-min/week for transportation and travel activities, then recreational activities worth 287.17 MET-min/week, and fixed activity have a value of 455.40 MET-min/week. The MET-minute/week value for work activities tends to be higher compared to other activity categories. This occurs because some elderly people have a variety of activities with moderate and severe intensity both when they are at home or when they are outside the home, such as gardening, biking, caring for a pet, or walking carrying heavy loads overhead. Recreational activities have a time value that is greater than the value of travel or transportation activities (Table 2).

The results of the study show that transport activities have a lower time value than the values in each category of physical activity. The results of this study indicate that activities for work and recreational activities provide the most support for total physical activity. From these data, it can be seen that in addition to the high work activities carried out both at home and outside the elderly, it still takes time to do recreational activities even though it has to compensate for high work activities.

Most of hypertension the elderly in Posbindu Sehat source in Kangkung Village, Mranggen Subdistrict, Demak Regency have moderate physical activity category. The results of this study indicate that although travel or transportation activities tend to be lower, the elderly with hypertension in Posbindu Healthy Resources in Kangkung Village, Mranggen Subdistrict, Demak Regency reach the minimum METminute/week criteria for the criteria of healthy elderly with more physical activity, moderate-intensity, when working, leisure, or travel. Based on data on the total physical activity of elderly people with hypertension, the amount of MET-minutes/week is $93.7 \%$ higher than that of elderly patients with male hypertension. Elderly people with hypertension who tend to have low physical activity are mostly caused by low work activities. This happens due to the degenerative process.

Physical activity that tends to be low will increase the frequency of the heart rate so the heart muscle must work harder each contraction. The stronger the heart muscle pumps, the more pressure it is placed on the arteries. So, that low activity tends to be the cause of someone experiencing health problems, especially cardiovascular

Table 2: Frequency distribution of respondents based on the mean physical activity of hypertensive elderly respondents in Kangkung Village, Mranggen District, Demak Regency

\begin{tabular}{ll}
\hline Physical activity & Average \\
\hline Work activities (MET-minutes/week) & 1302.22 \\
Transportation activities (MET-minutes/week) & 168.57 \\
Recreational activities (MET-minutes/week) & 287.17 \\
\hline
\end{tabular}


disease [21]. Doing physical activity every day for at least 30 min can reduce cardiovascular morbidity and mortality. Activities that need to be carried out include gardening, yard sweeping, biking, and playing with children. Regular physical activity is recommended to improve physical fitness; help build and maintain healthy bones, muscles, and joints and can reduce the risk of heart disease and help control blood pressure [22]. One of the efforts to control risk factors for hypertension is to be diligent in physical activities [2]. All sports activities, body movements, work, recreation, and all daily activities to activities during vacation or leisure time are some of the scopes of physical activities that can be carried out by everyone [3]. It can be concluded that the elderly who have heavy physical activity tend to have mild blood pressure and vice versa. Elderly respondents who have mild physical activity tend to be more at risk of severe hypertension. Hence, physical activity can affect hypertension in the elderly.

\section{Conclusion}

These results indicate there are a significant relationship and influence between physical activity and high blood pressure (hypertension) in the elderly with hypertension in Posbindu Sumber Sehat in Kangkung Village, Mranggen District, Demak Regency.

Elderly people with hypertension in POSBINDU Sumber Sehat in Kangkung village have an average of healthy physical activity because they have reached the minimum MET-minutes/week criteria for healthy elderly people by doing more moderate-intensity physical activity when working, recreation, or traveling, which is more than $600 \mathrm{MET} /$ week. It is hoped that the elderly can maintain and increase their activities by adding other activities with moderate to high intensity to reduce blood pressure.

\section{References}

1. Ministry of Health Republic of Indonesia. Riset Kesehatan Dasar (RISKESDAS) 2013, Laporan Nasional 2013; 2013.

2. The Indonesian Ministry of Health. Infodatin Lanjut Usia (lansia), Pusat Data dan Informasi Kementerian Kesehatan RI; 2016.

3. Suiraoka IP. Degenerative diseases: recognizing, preventing, and reducing risk factors 9 Degenerative diseases. Jakarta
Nuha Med. 2012; 57-139.

4. Eliopoulos C. Gerontological Nursing. Philadelphia, PA: Lippincott Williams \& Wilkins; 2013.

5. Sherwood LI. Fisiologi Manusia. Jakarta: EGC; 2011.

6. Buku Ajar Keperawatan Medikal Bedah. $12^{\text {th }}$ ed. Jakarta: EGC; 2014.

7. Stanley M, Beare PG. Buku Ajar Keperawatan Gerontik. Jakarta: EGC; 2006.

8. Aspiani RY. Buku Ajar Asuhan Keperawatan Gerontik Aplikasi NANDA, NIC, NOC. Jakarta: Trans Info Media; 2014.

9. Data Center and Information Ministry of Health R of I. Situasi Kesehatan Jantung, (Kementerian Kesehatan RI). Jakarta: Kementerian Kesehatan RI; 2014. https://doi.org/10.24252/bio. v5i1.3429

10. Manungkalit M. The difference in the effectiveness of the 2012 Physical Fitness Exercise (SKJ) and warm foot soaking in reducing blood pressure in the elderly with mild hypertension, J Ners Lentera. 2016;4:111-20 https://doi.org/10.31000/jkft. v512.3918

11. Khomarun K, Nugroho MA, Wahyuni ES. The effect of physical activity on morning walks on lowering blood pressure in the elderly with stage I hypertension at the Elderly Posyandu in Makamhaji Village. Int J Health Sciences. 2014; 106-214 https:// doi.org/10.31219/osf.io/59hb2

12. Mutiarawati R. Hubungan Antara Riwayat Aktivitas Fisik dengan Kejadian Hipertensi Pada Usia 45-54 Tahun Study Di Wilayah Kelurahan Tlogosari Kulon Semarang Tahun 2009, Universitas Negeri Semarang; 2009. https://doi.org/10.14710/jnc.v1i1.682

13. Services, USD of $\mathrm{H}$ and $\mathrm{H}$. 2008 Physical Activity Guideline for Americans. Washington, DC: US Government; 2008.

14. Regency CSA of D. Statistik Daerah Kabupaten Demak Tahun 2015. Demak: Badan Pusat Statistik Kabupaten Demak; 2015.

15. Soesanto $E$. Analisis faktor faktor yang berhubungan dengan praktik lansia hipertensi dalam mengendallkan kesehatannya di puskesmas mranggen demak. Fikkes. 2012;3(2):98-106. https://doi.org/10.33757/jik.v1i1.38

16. Setiadi N. Konsep dan Praktek Penulisan Riset Keperawatan. $2^{\text {nd }}$ ed. Jakarta: Graha ilmu; 2013.

17. Soekidjo N. Metodologi Penelitian Kesehatan. Jakarta: PT Rineka Cipta; 2016.

18. Febby Haendra Dwi Anggara NP. Factors Related to blood pressure at Telaga Murni Health Center West Cikarang. J IIm kesehatan 2013;5(1):20-5. https://doi.org/10.25311/keskom. vol3.iss5.122

19. Mayasari NF, Rosalina IH. Hubungan Aktivitas Fisik Dengan Tekanan Darah Pada Lansia Penderita Hipertensi di Kelurahan Banyumanik Kota Semarang. Semarang: STIKes Ngudi Waluyo; 2015. https://doi.org/10.38102/jsm.v1i2.42

20. Fatmah F. Elderly Nutrition. Jakarta: PT Penerbit Erlangga;2010. Gizi Usia Lanjut. Jakarta: PT Penerbit Erlangga; 2010.

21. Sherwood L, Manusia F. Fisiologi Manusia: Dari Sel ke Sistem. Jakarta: EGC; 2014.

22. Harikedua VT, TandoNM. Physical activity and eating patterns with obesity are central to religious leaders in Manado City. $J$ Gizindo. 2012;4(1):289-98.https://doi.org/10.37311/jnj.v2i1.4477 